\title{
EFEKTIVITAS KKG AGAMA HINDU MELALUI PRAKTEK DAN SISTEM UMPAN BALIK DALAM MENINGKATKAN KOMPETENSI GURU MENYUSUN RPP INOVATIF BERKARAKTER
}

\author{
Studi Pada Jenjang Sekolah Dasar Gugus 1 \\ Kec. Blahbatuh, Kab. Gianyar 2012/2013
}

\author{
Oleh: \\ I Ketut Kalpadiana \\ Kementerian Agama Kabupaten Gianyar Jalan Kepundung Nomor 8 \\ ketutkalpadiana@gmail.com
}

\begin{abstract}
The training strategy with the feed-back technique was designed to be applied in three cycles. The result of the KKG activity through the training with feed-back technique has been proven to have effect in increasing the commitment of the Hinduism teachers within the elementary schools included in cluster 1 in Blahbatuh district around the school year of 2012/2013 in completing the Learning Plan (RPP) with innovative and characterized ideals. The work indicators: at least $90 \%$ of the number of the teachers has indicated the good commitment in deciding the assessment instrument (the mean value of 4,00-5,00) within the scale of 1-5 which was achieved during the cycle 3 with the accomplishment of $100 \%$. Besides, the teacher competence in deciding the assessment instrument that conformed to the 2013 curriculum reached $100 \%$ as well.
\end{abstract}

\begin{abstract}
Abstrak
Strategi Kerja Praktek dengan Teknik Umpan Balik, dirancang dalam 3 (tiga) siklus. Hasil penelitian Kegiatan KKG melalui Kerja Praktek dengan teknik Umpan Balik, terbukti dapat meningkatkan komitmen guru-guru agama Hindu Sekolah Dasar Gugus I Kecamatan Blahbatuh Th. Pelajaran 2012/2013 dalam menyusun RPP Inovatif Berkarakter. Indikator kinerja: Sekurang-kurangnya 90\% guru menunjukkan komitmen yang baik dalam menyusun Instrumen Penilaian (nilai rata-rata $4,00-5,00$ ) dalam skala 1-5, tercapai pada akhir siklus III dengan pencapaian 100\%. Sedangkan Kemampuan guru dalam menyusun Instrumen penilain sesuai dengan ketentuan Kurikulum 2013 juga mencapai $100 \%$.
\end{abstract}

Kata kunci: kemampuan, kerja praktek, umpan balik.

\section{PENDAHULUAN}

\subsection{Latar Belakang Masalah}

Pembuatan RPP adalah sangat urgen, menurut Hamzah B. Uno (2006: 4): Perbaikan kualitas pembelajaran haruslah diawali dengan perbaikan desain pembelajaran. Perencanaan Pembelajaran dapat dijadikan titik awal dari upaya perbaikan kualitas pembelajaran. Namun disatu sisi dalam realita dilapangan masih banyak sekali 
guru-guru khususnya guru agama Hindu yang kesulitan dalam membuat RPP yang berkarakter, sehingga menghambat pencapaian tujuan dari proses pembelajaran. Wadah kegiatan yang bersifat kordinasi, serta bertukar pikiran seperti KKG (Kelompok Kerja Guru) sangat dibutuhkan keberdaanya, dan sampai saat ini merupakan salah satu alternatif dalam memecahkan berbagai permasalahan yang dihadapi guru.

Beberapa faktor yang diduga sebagai penyebab lemahnya kemampuan guru agama Hindu khususnya di Kecamatan Blahbatuh, Kabupaten Gianyar adalah Kurangnya tuntutan supervisor (Kepala Sekolah dan Pengawas Sekolah), karena masih memperkenankan penggunaan RPP yang tidak mencerminkan penanaman karakter dengan anggapan bahwa pembelajaran agama sudah pasti merefleksikan penanaman karakter bangsa. Selama ini sebagian guru-guru Sekolah Dasar (SD) belum memiliki persamaan persepsi tentang esensi dari RPP berkarakter, karena terbatasnya pertemuan, atau sosialisasi antarguru agama Hindu. Guru dalam mengajar di depan kelas terkadang berbeda dengan skenario yang tertulis dalam RPP tersebut. Beranjak dari hal tersebut maka KKG yang di dalamnya terdapat Kerja Praktek adalah pilihan strategi yang diharapkan mampu mengatasi masalah rendahnya komitmen dan kemampuan guru-guru menyusun RPP.

Teknik Umpan Balik terhadap hasil kerja para guru diharapkan dapat memberikan penguatan dan arah untuk melakukan penyempurnaan RPP sesuai dengan tuntutan Peraturan Menteri Pendidikan Nasional No. 41 tahun 2007 yang mengubah paradigma proses pendidikan dari pengajaran menjadi pembelajaran dan mengubah strategi ekspositori menjadi diskoveri inkuiri yang dalam penelitian ini disebut RPP Inovatif Berkarakter.

\subsection{Rumusan Masalah}

Masalah-masalah pokok dalam penelitian ini adalah:

1. Apakah Kegiatan KKG dapat meningkatkan komitmen guru-guru agama Hindu SD Gugus 1 Kecamatan Blahbatuh Kabupaten Gianyar dalam menyusun RPP Inovatif Berkarakter?

2. Apakah Kegiatan KKG dapat meningkatkan kemampuan guru-guru agama Hindu SD Gugus 1 Kecamatan Blahbatuh Kabu- paten Gianyar dalam menyusun RPP Inovatif Berkarakter ?

\subsection{Metode Penelitian}

Desain penelitian ini adalah Penelitian Tindakan model Stephen Kemmis, yang berlokasi Sekolah Dasar gugus I Kecamatan Blahbatuh yang terdiri dari enam sekolah yaitu SDN 1 s.d. SDN 5 Saba.

Alasan mendasar penelitian ini dilaksanakan di gugus I menginggat wilayah tersebut merupakan wilayah yang menjadi tugas kepengawasan dari peneliti. Selain itu pada Gugus I Kecamatan Blahbatuh, sebagian besar guru agama Hindu Belum Memiliki komitmen dan kemampuan dalam menyusun RPP Inovatif Berkarakter, sehingga dalam proses pembelajaran dikelas cendrung bersifat formalitas.

Subjek Penelitian adalah 7 dari 11 orang guru mata pelajaran agama Hindu Sekolah Dasar gugus 1 di Kecamatan Blahbatuh Kabupaten Gianyar, meliputi guru agama Hindu SDN 1 s/d SDN 6 Saba. Objek penelitian ini adalah kemauan dan kemampuan guru-guru membuat RPP Inovatif Berkarakter. Sebagai variabel bebas adalah "strategi Kerja Praktek pada kegiatan KKG dengan teknik Umpan Balik", dan variabel terikat adalah "komitmen" dan "kemampuan" guru menyusun RPP Inovatif Berkarakter

Penelitian ini direncanakan dalam 3 (tiga) siklus. Perencanaan penelitian dibagi dalam langkah-langkah sebagai berikut:

(1) Observasi dan Refleksi Awal Kegiatan ini dimaksudkan untuk mengetahui kemampuan awal guru-guru menyusun RPP sebelum dilaksanakan tindakan. Peneliti/ supervisor mengumpulkan masing-masing sebuah RPP yang telah dibuat guru. Kemudian dikaji dan dinilai, diberikan umpan balik berdasarkan 8 (delapan) komponen sesuai dengan format penilaian RPP dalam Panduan Penyusunan Perangkat Portofolio Sertifikasi Guru Dalam Jabatan;

(2) Siklus I Siklus I ini terdiri dari beberapa tahapan yaitu (a) Perencanaan, siklus pertama ini direncanakan terdiri dari: Pembentukan kelompok: guru agama Hindu, serta jadwal pertemuan KKG; Informasi: Tentang teknik perumusan langkah-langkah pembelajaran RPP Inovatif Berkarakter dengan pola konvensional, oleh su- 
pervisor (peneliti); Diskusi: Diskusi terbimbing dalam rumpun mata pelajaran. Bahan diskusi adalah RPP pertama yang telah dinilai dan diberi umpan balik; Praktek: tugas terpantau (ditentukan batas waktunya) untuk merevisi RPP pertama, menjadi RPP yang lengkap sesuai format penilaian dalam sertifikasi. (b) Pelaksanaan tindakan, sesuai dengan jadwal dan rencana kegiatan yang telah ditentukan dalam perencanaan siklus I. (c) $\mathrm{Ob}$ servasi, berlangsung selama kegiatan (dalam proses) untuk: mengumpulkan data tentang komitmen guru dalam melaksanakan kegiatan, melakukan penilaian kemampuan guru dalam melakukan revisi RPP, melalui koleksi dokumen. (d) Refleksi, mengkaji hasil-hasil yang dicapai selama pelaksanaan tindakan, serta usaha dan rencana perbaikannya.

(3) Siklus II Siklus kedua ini, akan dilaksanakan seandainya hasil-hasil pada siklus I belum mencapai indikator kinerja. Pada apek Refleksi dilaksanakan dengan, mengkaji hasil-hasil yang dicapai selama pelaksanaan tindakan, serta usaha dan rencana perbaikannya jika masih dipandang perlu. (3) Siklus III akan dilaksanakan seandainya hasil-hasil pada siklus II belum mencapai indikator kinerja,

Terkait dengan sumber data, data-data yang dikumpulkan dalam penelitian ini adalah data primer yaitu data-data yang diperoleh secara langsung oleh peneliti. Data tersebut diperoleh dari pengamatan atau penilaian dokumen oleh peneliti. Untuk komitmen guru menyusun RPP Inovatif Berkarakter sumber datanya adalah aktivitas guru dalam pertemuan formal (KKG) serta aktifitas kerja di rumah.

Metode pengumpulan data pada penelitian ini adalah observasi, penilaian dokumen dan wawancara. Untuk Komitmen guru menyusun RPP Inovatif, metoda pengumpulan data adalah observasi dengan instrumen panduan observasi. Acuannya adalah definisi komitmen dari Glickman (dalam Piet Sahertian, 1944: 44) yaitu: "usaha dan dorongan serta waktu yang cukup banyak".

Sedangkan untuk Kemampuan guru menyusun RPP Inovatif, metode pengumpulan data adalah penilaian dokumen dengan instrumen. Acuannya adalah format penilaian RPP dalam sertifikasi guru. Data-data yang terkumpul dianalisis dengan analisis deskriptif dibantu dengan statistik sederhana. Data tentang komitmen guru menyusun RPP Inovatif Berkarakter, dianalisis dengan analisis deskriptif dengan metoda tabulasi dan grafik.

Dengan memperhatikan kondisi awal guruguru agama Hindu Tingkat Sekolah Dasar di Gugus I Kecamatan Blahbatuh, Kabupaten Gianyar, dari 3 orang guru agama Hindu senior yang mengikuti uji sertifikasi, bahwa ketiganya belum memiliki kemampuan menyusun RPP sesuai pedoman yang berlaku. Masih banyak guru (sekitar 90\%) tidak mampu menyusun RPP berkarakter atau tidak menggunakan RPP buatan sendiri dan umumnya RPP yang digunakan kurang inovatif.

Beranjak dari hal tersebut maka indikator kinerja dalam penelitian ini: Sekurang-kurangnya 90\% guru menunjukkan komitmen yang baik dalam menyusun RPP Inovatif (nilai rata-rata 4,00-5,00) dalam skala 1-5. Sekurang-kurangnya $90 \%$ guru menunjukkan kemampuan yang baik dalam menyusun RPP Inovatif (nilai ratarata 4,00-5,00) dalam skala 1 . Penelitian ini dilaksanakan berlangsung selama bulan Januari sampai dengan Maret 2013 (10 minggu).

\section{II.PEMBAHASAN}

RPP Inovatif adalah RPP pembaharuan yaitu RPP yang mengacu pada Peranturan Menteri Pendidikan Nasional No. 41 tahun 2007 tentang Standar Proses Pendidikan Dasar dan Menengah. Letak pembaharuan pada RPP Inovatif yaitu:

- Strategi pembelajaran adalah student centre oriented dengan pendekatan diskovery inkuiri.

- Secara tegas mencantumkan proses eksplorasi, elaborasi dan konfirmasi.

- Eksplorasi, tahap pengumpulan informasi yang luas dan mendalam tentang materi (fakta dan konsep) yang dipelajari.

- Elaborasi, tahap pengolahan/analisis informasi, membuat hipoptesis, menyelesaikan masalah, atau memunculkan gagasan baru, baik secara lisan maupun tulisan.

- Konfirmasi, tahap mengkomunikasikan hasil eksplorasi dan elaborasi, melaku- 
kan refleksi untuk memperoleh pengalaman belajar dan umpan balik serta penguatan oleh guru.

- Mengadopsi "model-model pembelajaran Inovatif" dengan langkah-langkah atau syntax yang sudah baku pada masing-masing model pembelajaran.

- Dilengkapi Tugas Terstruktur dan Kegiatan Mandiri Tak Terstruktur.

Pemberian tugas terstruktur dan kegiatan mandiri tak tersruktur adalah hal wajib dalam pelaksanaan kurikulum tingkat satuan pendidikan (KTSP).

- Untuk sekolah standar, alokasi waktu 0\%-60\% dari alokasi waktu tatap muka, diprogramkan sebagai pengembangan dan pengganti istilah ko-kurikuler atau tugas rumah.

- Untuk sekolah dengan kategori mandiri dengan sistem SKS setiap 45 menit kegiatan tatap muka, wajib melaksanakan penugasan terstruktur dan kegiatan mandiri tak terstruktur dengan alokasi waktu 25 menit.

Pendidikan Karakter merupakan perpaduan antara komponen kepribadian dan tindakan. Karakter lebih banyak dikaitkan dengan moral. Dalam hal ini adalah kualitas personal yang sesuai dengan yang oleh masyarakat dipertimbangkan sebagai ciri yang baik, dan digunakan sebagai tujuan pendidikan. Yang dimaksud dengan RPP Berkarakter adalah Rencana Pelaksanaan Pembelajaran yang di dalamnya mencerminkan penanaman nilai etika, moral dan budi pekerti. Pada hakekatnya RPP Berkarakter adalah RPP yang merefresentasikan sebelas prinsip dasar pendidikan karakter yang meliputi hal-hal sebagai berikut:
1. Pendidikan karakter mempromosikan nilai etika yang inti sebagai basis karakter yang baik

2. Karakter harus didefinisikan secara komperhensif yang mencakup pikiran, perasaan, dan tindakan

3. Pendidikan karakter yang efektif mempersyaratkan pendekatan yang terencana, proaktif, dan komperhensip yang mempromosikan nilai-nilai hakiki pada semua tingkat pendidikan.

4. Sekolah harus menjadi masyarakat yang peduli

5. Untuk mengembangkan karakter, siswa perlu memperoleh kesempatan untuk bertindak secara moral.

6. Pendidikan karakter yang efektif mencakup kurikulum yang challenging dan bermakna, serta menghargai semua pembelajaran dan menolong mereka untuk berhasil

7. Pendidikan karakter harus diarahakan untuk mengembangkan motivasi intrinsik siswa

8. Staf sekolah harus menjadi masyarakat moral dan berbagi tanggung jawab dalam pendidikan karakter serta berusaha untuk menunjukan nilai-nilai yang bisa dijadikan model oleh para siswa

9. Pendidikan karakter mempersyaratkan kepemimpinan yang bermoral

10. Sekolah harus melibatkan masyarakat sebagai patner dalam usaha membangun karakter

11. Evaluasi dalam pendidikan karakter harus mencakup pengukuran karakter sekolah, fungsi staf sekolah sebagai pendidik karakter yang berdampak pada

Tabel 5

Peningkatan Komitmen Guru-guru

\begin{tabular}{|c|l|c|c|c|c|}
\hline No. & \multicolumn{1}{|c|}{ Uraian } & Siklus I & Siklus I & Siklus II & $\begin{array}{c}\text { Total } \\
\text { Peningkatan }\end{array}$ \\
\hline 1. & Rata-rata komitmen & 3,42 & 3,86 & 4,86 & 1,44 \\
\hline 2. & Jumlah guru dengan nilai $4,00-5,00$ & 4 & 6 & 7 & 3 orang \\
\hline 3. & Persentase guru dengan nilai $4,00-5,00$ & $51 \%$ & $86 \%$ & $100 \%$ & $49 \%$ \\
\hline
\end{tabular}


Tabel 6

Peningkatan Kemampuan Guru-guru

\begin{tabular}{|c|l|c|c|c|c|c|}
\hline No. & \multicolumn{1}{|c|}{ Uraian } & Awal & Siklus I & Siklus I & Siklus II & $\begin{array}{c}\text { Total } \\
\text { Peningkatan }\end{array}$ \\
\hline 1. & Rata-rata kemampuan & 2,60 & 3,71 & 4,00 & 4,71 & 2,11 \\
\hline 2. & $\begin{array}{l}\text { Jumlah guru dengan nilai } \\
4,00-5,00\end{array}$ & 0 & 4 & 6 & 7 & 3 orang \\
\hline 3. & $\begin{array}{l}\text { Persentase guru dengan } \\
\text { nilai 4,00 - 5,00 }\end{array}$ & $0 \%$ & $71 \%$ & $86 \%$ & $100 \%$ & $29 \%$ \\
\hline
\end{tabular}

karakter siswa (Handarini, 2011: 6-8).

KKG (kelompok kerja guru) adalah wadah berkumpulnya guru-guru pada tingka pendidikan dasar (SD) yang berfungsi sebagai media koordinasi serta komunikasi terkait persamaan persepsi guna membahas berbagai permasalahan yang dihadapi dalam proses pembelajaran. Dengan demikian strategi kerja praktek dalam kregiatan KKG memilki peran yang sangat besar, sebab mengacu pada kerucut pengalaman belajar dari Peter Sheal, terlihat bahwa pengalaman belajar yang optimal akan dicapai, jika peserta belajar sampai pada tingkat melakukan dan mengatakan. Melakukan dalam hal ini adalah praktek penyusunan RPP, dan mengatakan dilaksanakan dalam bentuk presentasi hasil kerja.

Ahmad Rohani (2004: 6) mengatakan: belajar yang berhasil mesti melalui berbagai macam aktifitas, baik aktifitas fisik maupun psikis. Pakar Psikologi Pendidikan J. Peaget (dalam Ahmad Rohani, 2004: 7) mengatakan: Seseorang berpikir sepanjang berbuat. Tanpa berbuat seseorang tidak akan berpikir. Agar ia berpikir sendiri (aktif) maka ia harus diberi kesempatan untuk berbuat sendiri.

\subsection{Peningkatan Komitmen guru-guru se-} lama pelaksanaan tindakan.

Tabel 5 menunjukkan kecendrungan peningkatan nilai komitmen guru-guru menyusun RPP Inovatif Berkarakter .

Interpretasi:

- Peningkatan nilai komitmen guru-guru membuat RPP Inovatif dari siklus I ke siklus III sebesar 1,44 (dalam skala 15) yaitu dari 3,42 menjadi 4,86 .

- Jumlah guru yang mencapai nilai lebih dari 4,00 sebanyak 7 orang (100\%).
Persentase kenaikan itu adalah 49\% yaitu dari 51\% menjadi 100\%.

- Jadi indikator kinerja untuk peningkatan komitmen guru-guru sebesar 90\% dari jumlah guru sudah tercapai pada siklus III dengan pencapaian 100\%.

\subsection{Peningkatan Kemampuan Guru-guru selama pelaksanaan tindakan}

Tabel 6 menunjukkan kecendrungan peningkatan kemampuan guru-guru Menyusun Instrumen penilaian.

Grafik. I

Grafik Histogram Peningkatan Kemampuan Guru Agama Hindu Menyusun RPP Inovatif Berkarakter

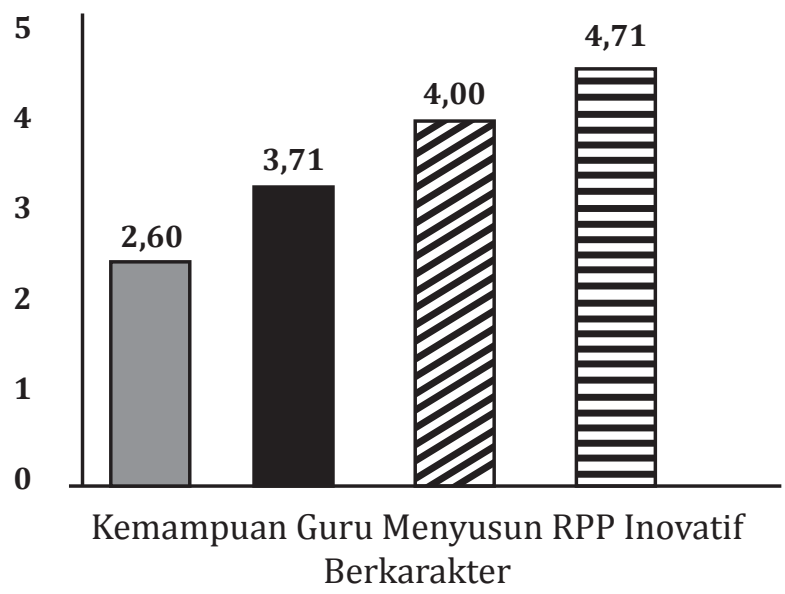

Keterangan Gambar :

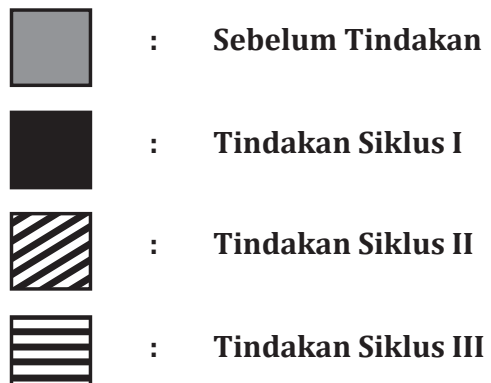


Interpretasi :

1) Terjadi peningkatan kemampuan guruguru Menyusun Instrumen penilaian dari awal ke siklus III sebesar 2,11 (dalam skala 1-5) yaitu dari 2,60 menjadi 4,71.

2) Jumlah guru yang mencapai nilai 4,005,00 meningkat sebanyak 3 orang dari 7 orang. Persentase guru yang mencapai nilai 4,00-5,00 adalah $100 \%$ dari 7 orang guru.

3) Jadi indikator kinerja tercapai pada siklus III, dengan pencapaian $100 \%$.

\section{Dari Grafik Histogram I terlihat:}

Nilai kemampuan guru-guru naik monoton (terus meningkat) berbentuk parabolis. Artinya kenaikan tajam terjadi pada siklus I (dari kondisi awal sampai akhir siklus I) dari nilai 2, 60 menjadi 3,71. Selanjutnya kenaikannya agak landai dari 3,71 menjadi 4,00 pada siklus II, dan dari 4,00 menjadi 4,71 pada siklus III

\section{Dari Grafik Histogram I I terlihat:}

persentase guru-guru yang mencapai nilai 4,00-5,00 dari siklus I ke siklus III naik secara monoton dengan kenaikan 29\%.

Kenaikan dari kondisi awal ke siklus I terjadi kenaikan yang cukup tajam (dari $0 \%$ menjadi 71\%), tapi pada siklus II (akhir sikuls I sampai akhir siklus II) terjadi tidak terlalu tajam yakni (dari $71 \%$ menjadi 86\%).

Selanjutnya kenaikan dari akhir siklus II ke akhir siklus III tampak tidak terlalu tajam yaitu dari $86 \%$ menjadi $100 \%$.

\section{III.PENUTUP}

\subsection{Simpulan:}

Membalik paradigma pendidikan dari paradigma pengajaran menjadi paradigma pembelajaran atau membalik dari teacher centre oriented menjadi student centre oriented bukanlah hal mudah bagi guru. Kunci keberhasilan guru membuat RPP Inovatif, adalah pada kemampuan guru memahami dan menggunakan model-model pembelajaran Inovatif. Setiap proses pembelajaran (termasuk untuk orang dewasa) hendaknya memunculkan kompetensi secara utuh meliputi ranah kognitif, psikomotor dan afektif. Afektif, yang meliputi aspek sikap, minat, konsep diri, nilai dan moral, akan menunjang
Grafik. II

Grafik Histogram Persentase Peningkatan Kemampuan Guru Agama Hindu Menyusun RPP Inovatif Berkarakter

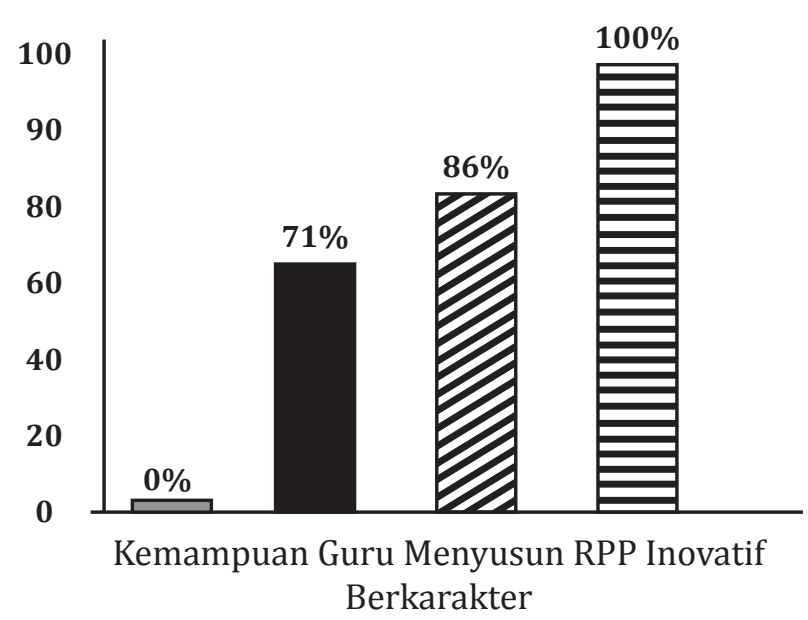

Keterangan Gambar :

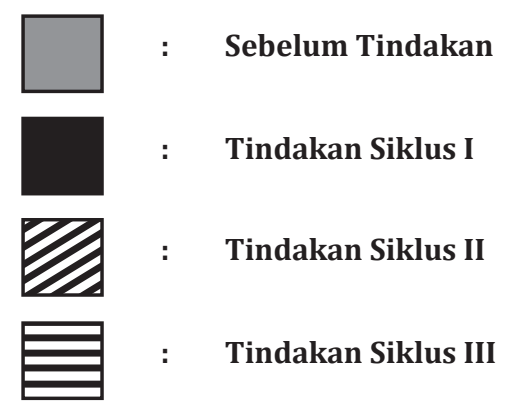

pencapaian kognitif dan psikomotor.Minat berhubungan dengan dorongan atau motivasi. Dalam meningkatkan kemauan seseorang untuk berbuat, maka motivasi harus ditumbuhkan. Motivasi jangan sekedar ekstrinsik, tapi harus muncul motivasi instrinsik. Dorongan untuk memenuhi kebutuhan akan pengakuan dan penguasaan ilmu pengetahuan harus ditumbuh kembangkan.

Seseorang akan mau melaksanakan sesuatu yang baru yang bertentangan dengan kebiasan lama, apabila pola pikirnya telah berubah. Pola pikir seseorang akan berubah, jika telah memiliki pemahaman yang baik terhadap konsep yang baru tersebut. Jadi agar seseorang mau melaksanakan sesuatu yang baru, maka langkah pertama adalah memberi pemahaman yang benar.

Pemahaman seseorang akan mendekati sempurna jika kepadanya diberi kesempatan untuk melakukan praktek, dan mempresentasikan hasil kerjanya sendiri. Maka pola pembelajaran yang hanya mengedepankan ekspos fakto harus dihindarkan dan diperbanyak pola-pola kerja 
praktek. Pemberian umpan balik sangat penting untuk mengarahkan pola pikir dalam pemecahan masalah dan sebagai petunjuk arahan kerja untuk mencapai hasil belajar yang optimal. Model pembelajaran untuk orang dewasa (andragogi) hendaknya menjadi perhatian dan dilaksanakan dalam setiap kegiatan pembelajaran, karena orang dewasa tidak senang diperlakukan sebagai anak-anak.

Dari hasil-hasil yang dipaparkan pada pembahasan di atas, dapat dibuat simpulan bahwa hipotesis tindakan telah terbukti:

1. Kegiatan KKG Melalui Kerja Praktek dengan teknik Umpan Balik, terbukti dapat meningkatkan komitmen guru-guru agama Hindu Sekolah Dasar Gugus I Kecamatan Blahbatuh Th. Pelajaran 2012/2013 dalam menyusun RPP Inovatif Berkarakter.

Indikator kinerja: Sekurang-kurangnya 90\% guru menunjukkan komitmen yang baik dalam menyusun RPP Inovatif (nilai rata-rata 4,00-5,00) dalam skala $1-5$, tercapai pada akhir siklus III dengan penca- paian 100\%. Sedangkan kemampuan guru dalam menyusun RPP Inovatif Berkarakter juga mencapai $100 \%$

\subsection{Saran}

Atas hasil-hasil yang dicapai dalam penelitian ini, penulis rekomendasikan kepada pihakpihak yang terkait dengan upaya peningkatan mutu pendidik yaitu:

a. Para Kepala Sekolah, untuk merevisi caracara peningkatan mutu pendidik, dari model ekspos fakto menjadi bentuk kerja praktek nyata secara berkelanjutan. Model-model ekspos fakto yang banyak dilakukan sebelumnya, terbukti tidak mampu memberdayakan guru-guru.

b. Para Pengawas Pendidikan, bahwa peningkatan mutu pendidik bukan suatu hal sederhana. Perlu upaya berkelanjutan untuk melaksanakan supervisi, agar pola pembelajaran guru-guru tidak kembali lagi pada pola konvensional, karena pola tersebut tidak sesusai dengan Peraturan Menteri Pendidikan Nasional No.41 tahun 2007.

\section{DAFTAR PUSTAKA}

Badan Standar Nasional Pendidikan. 2006. Panduan Penyusunan Kurikulum Tingkat Satuan Pendidikan. Jakarta: BSNP.

Bulletin Kent Mathematics Project (1990).

Depdikbud. 1992. Buku Pedoman Penyelenggaraan Musyawarah Guru Mata Pelajaran. Jakarta : Depdikbud.

Depdikbud. 1993. Dengan Pemantapan Kerja Guru Kita Siapkan Sumber Daya Manusia yang Berkualitas Untuk Menyongsong Pembangunan Jangka Panjang Tahap II. Jakarta : Depdikbud.

Depdiknas. 2003. Kurikulum Berbasis Kompetensi. Jakarta : Depdiknas.

Depdiknas. 2005. Peraturan Pemerintah Nomor 19 tahun 2005 tentang Standar Nasional Pendidikan. Jakarta : Depdiknas.

Depdiknas. 2007. Peraturan Menteri Pendidikan Nasional No. 16 tahun 2007 tentang Kualifikasi Akademik dan Kompetensi Guru. Jakarta : Depdiknas.

Depdiknas. 2007. Peraturan Menteri Pendidikan Nasional No.41 tahun 2007 Tentang Standar Proses Pendidikan Dasar dan Menengah. Jakarta : Depdiknas.

Dirjen Pendidikan Tinggi. 2007. Panduan Penyusunan Perangkat Portofolio Sertifikasi Guru Dalam Jabatan. Jakarta : Depdiknas.

Direktorat Dikmenum. 1999. Manajemen Peningkatan Mutu Berbasis Sekolah. Jakarta : Depdiknas. 